\title{
Information Disclosure and Cost of Equity: Evidence from Subsidy of New Energy Industry
}

\author{
Yi-Chang Chen ${ }^{1}$ \\ ${ }^{1}$ School of Finance and Accounting \\ Fuzhou University of International Studies and Trade, China
}

\author{
Zhengdong $\mathrm{Wu}^{3 *}$, \\ ${ }^{3}$ Department of Computer Science and Engineering, \\ Nanfang College of Sun Yat-sen University, China \\ *Corresponding author
}

\author{
Manqi Jiang ${ }^{2}$ \\ ${ }^{2}$ International Accounting and Finance, \\ Aston University, UK
}

\author{
Jiaqi $\mathrm{Luo}^{4}$ \\ ${ }^{4}$ Accounting School, Nanfang College of Sun Yat-sen \\ University, China
}

\begin{abstract}
This paper explores the impact of the level of information disclosure on the cost of equity for the subsidy policies of the new energy industry. We find the impact of government subsidy policies on information disclosure in the new energy industry, and further studies the correlation between information disclosure level and cost of equity. We provide evidence and explanations for the development of new energy industry and government subsidy policy. The empirical results show that information disclosure is negatively correlated with the cost of equity capital. Also, the results show that government subsidies have an impact on the level of information disclosure of new energy listed companies.
\end{abstract}

Keywords - information disclosure; subsidy policies; new energy industry; cost of equity

\section{INTRODUCTION}

Accounting information affects the direct link between the market' $s$ enterprise information and the cost of capital in the equilibrium environment, and with the increasing attention of the public on information disclosure in the market, the quality of information disclosure of the listed companies is particularly important (Fama and French, 1992; Fama and French, 1993; Fama and French, 1997). In recent years, the government has strongly supported the development of the new energy industries Government subsidies have affected the performance of the new energy listed companies to a certain extent, so the disclosure of information affected by government subsidies enables users to better understand the experience of enterprises.

Botosan (1997), one of the first scholars to propose the correlation between the level of information disclosure and the cost of equity capital, put forward this idea in 1997. But the final findings suggest that there is not enough valid evidence to show that the level of information disclosure is related to the cost of equity for some companies. While for others the more information disclosed, the lower the capital cost. Botosan (2000) further found that for those companies that had previously come to the conclusion that disclosure was more adequate and the lower the cost of capital, predictive information and some nonfinancial pointers could help reduce the cost of equity. Botosan and Plumlee (2002) expanded the research sample, after controlling the risk factor and enterprise size, to conclude that the increase in the level of information disclosure can reduce the cost of equity.

Wang and Jiang (2004) examined the correlation between the cost of equity of enterprises listed on the SSE before 2002 and the level of voluntary information disclosure. The results show that the higher the level of information disclosure of the listed companies, the more conducive it is to reduce the cost of equity. The capital costs of the listed companies with equity refinancing, which are studied by Huang and Xiao (2006), are affected by the quality of information disclosure in the past 5 years. Sun (2010) analyzes the correlation between information disclosure and capital cost from the perspective of liquidity and risk, and the research demonstrates that the two are negatively correlated. Zhang and Guo (2015) indicates that the listed companies that choose voluntary disclosure mode will improve with the disclosure level of internal control information, and the trend of decreasing the cost of equity will increase.

Government subsidy policy can promote the development of industry and play an incentive role. The finding of the skuras and Tsekouras (2008) prove that government subsidies can stimulate technological innovation and thus increase their productive capacity. The study by Lv (2010) found that machinery, equipment and instruments are the three industries with the highest coverage of government subsidies, while hydropower, natural gas, real estate and social services are the ones with the highest government subsidies. It can be seen that the support of government subsidies for the development of China's industry is powerful. Yang et al. (2016) found that some local governments provide subsidies to enterprises facing threats of delisting. One is to prevent enterprises from delisting, and the other is that business results can bring tax revenue and increase GDP. Therefore, for accounting information users, the role of information disclosure is very important (Copeland and Galai, 1983; Rosenberg et al., 1985; Chen and Xu, 1991; Botosan, 1997; Verrecchia, 1999; Bushman and Smith, 2001; Hail, 2002; Chen et al., 2003; Gode and Mohanram, 2003; Chen et al., 2004; 
Easley and O'hara, 2004; Pittman and Fortin 2004; Wang, 2013; Tang, 2018; Tu, 2017; Wang and Shen 2018).

\section{METHOD}

We construct a multi-regression analysis model based on the correlation between the level of information disclosed and the cost of equity above as follows.

\section{A. Empirical Regression Model}

In order to verify the research hypothesis of this experiment and understand the relationship between the level of information disclosure and the cost of equity, this study takes the sample of the new energy industry listed on Shenzhen Stock Exchange, and uses the cost of equity (COE) as the variable to conduct statistical model analysis. The regression model 1 is as follows:

$$
\begin{aligned}
\operatorname{COE}_{\mathrm{i}, \mathrm{t}}= & \alpha_{0}+\beta_{1} \text { DISCORE }_{i, t-1}+\beta_{2} \operatorname{SIZE}_{i, t-1}+\beta_{3} \text { BM }_{i, t-1}+\beta_{4} \text { LEV }_{i, t-1} \\
& +\beta_{5} \text { BETA }_{i, t-1}+\beta_{6} \operatorname{INDUSTRY~}_{i, t-1}+\beta_{7} \text { YEAR }_{i, t-1}+\varepsilon_{i, t}
\end{aligned}
$$

Based on the influence of government subsidy policy on information disclosure, we study the relationship between information disclosure on the cost of equity. The government subsidy is used as the multiplication of the regulator variable GOV and GOV*INDUSTRY, and the regression model 2 is obtained:

$\operatorname{COE}_{\mathrm{i}, \mathrm{t}}=\alpha_{0}+\beta_{1}$ DISCORE $_{i, t-1}+\beta_{2} \operatorname{GOV}_{i, t-1}+\beta_{3}$ DISCORE $_{i, t-1} * G O V_{i, t-i}+\beta_{3} \operatorname{SIZE}_{i, t-1}$ $+\beta_{4} B M_{i, t-1}+\beta_{5} L E V_{i, t-1}+\beta_{6} B E T A_{i, t-1}+\beta_{7} \operatorname{INDUSTRY~}_{i, t-1}+\beta_{8}$ YEAR $_{i, t-1}+\varepsilon_{i, t}$

Where DISCORE is The Level of Information Disclosure; SIZE is Enterprise Size; BM is Book to Market Ratio; LEV is Liability ratio; BETA is Systematic risk; INDUSTRY is Industry variables; GOV is Government Subsidy; YEAR is Variables and $\varepsilon$ is residual term

\section{B. Data sources}

The research samples are 65 listed companies of the new energy on Shenzhen Stock Exchange from 2010 to 2017. The empirical data sources required for this research are derived from the following sources:

\section{1) Wind database and the database of Tai'an.}

In order to obtain the data of various financial variables required in the empirical analysis, the data of this research was obtained from the financial database of listed companies provided by the Wind database and the database of Tai'an.

2) The official website of Shenzhen stock exchange:

The measurement of the level of information disclosure in this paper was obtained by the official website of the Shenzhen Stock Exchange.

\section{RESULTS}

\section{A. Sample selection}

Based on the new energy listed companies in the eight years from 2010 to 2017, 139 listed companies were selected as the research sample. Firstly, we deleted the companies that did not have a comprehensive and effective announcement on the Shanghai Stock Exchange to evaluate the level of information disclosure or data damaged. Finally, 65 valid samples were obtained.

\section{B. Narrative statistical analysis}

Table 1 shows descriptive statistics of the variables of the relationship between the level of information disclosure and the cost of equity. First, the average of the cost of equity (COE) is 0.019 , the minimum value is -0.617 , the maximum value is 0.913 , which shows that the average cost of using equity to raise funds by the expected sample company is about 0.019 . The lowest risk and the highest risk bear the cost of capital costs of only -0.617 and 0.913 , respectively. Furthermore, the average of DISCORE is 0.834 , and the most transparent company receiving 1 point, while the most opaque company receiving only 0 . The mean value of BM, LEV and BETA are $0.972,0.471$ and about 1.206 , separately. The Liability ratio is $47 \%$, on average, indicating that the average liability in the capital structure of the sample company is about 0.47 of total assets. So it can be understood that the source of funds of the sample companies is mainly equity Fund.

TABLE I DESCRIPTIVE STATISTICS

\begin{tabular}{|l|l|l|l|l|l|}
\hline & Mean & Max. & Minimum & SD & $\begin{array}{l}\text { Sum Sq. } \\
\text { Dev. }\end{array}$ \\
\hline COE & 0.019 & 0.9135 & -0.61734 & 0.252 & 33.099 \\
\hline DISCORE & 0.834 & 1 & 0 & 0.371 & 71.776 \\
\hline GOV & 0.963 & 1 & 0 & 0.187 & 18.305 \\
\hline LEV & 0.471 & 1.044 & 0.039546 & 0.204 & 21.741 \\
\hline SIZE & 3.112 & 3.221 & 3.029291 & 0.036 & 0.693 \\
\hline BETA & 1.206 & 19.472 & -1.1958 & 0.887 & 408.473 \\
\hline BM & 0.972 & 6.888 & 0.068 & 0.819 & 348.245 \\
\hline
\end{tabular}

\section{Relevance Analysis}

The correlation coefficients between the explanatory variables are basically less than 0.5 in Table 3 , which shows that the collinearity between the explanatory variables is not serious. Thus in the subsequent multiple regression analysis, it does not lead to inaccurate coefficient estimation and inferences affecting empirical results due to the problem of severe collinearity between explanatory variables. As can be seen from the table, the cost of equity (COE) is negatively correlated with systemic risk (BETA) and positively correlated with the book to market ratio (BM), liability ratio (LEV), government subsidy (GOV) and Enterprise size (SIZE).

TABLE II CORRELATIONS

\begin{tabular}{|c|c|c|c|c|c|c|c|}
\hline & COE & DISCORE & GOV & LEV & SIZE & BETA & BM \\
\hline COE & 1 & & & & & & \\
\hline DISCORE & -0.085 & 1 & & & & & \\
\hline GOV & 0.004 & 0.078 & 1 & & & & \\
\hline LEV & 0.105 & -0.097 & -0.141 & 1 & & & \\
\hline SIZE & 0.094 & 0.1547 & 0.126 & 0.114 & 1 & & \\
\hline BETA & 0.010 & -0.002 & 0.047 & -0.009 & 0.100 & 1 & \\
\hline BM & 0.015 & -0.000 & -0.098 & 0.569 & -0.070 & -0.092 & 1 \\
\hline
\end{tabular}

Results from the table above can be found, correlation coefficients indicate that the cost of equity and the level of information disclosure are significantly negatively correlated, 
and that improving the level of information disclosure can enable enterprises to obtain lower capital costs, and initially supports the expected study hypothesis. The cost of equity is significantly positively correlated with the enterprise size, which is inconsistent with the expected hypothesis. It also confirms that there is no theoretical scale effect in China's securities market.

\section{ANALYSIS OF EMPIRICAL RESULTS}

In order to further verify the level of information disclosure, enterprise size, book to market ratio, Liability ratio, systemic risk and government subsidies on the cost of equity. The following is a multivariate regression analysis method for the next analysis of the two models. Comparing the direction and impact of the level of information disclosure on the cost of equity funds in the case of government subsidies. The regression results are as follows:

Table 3 is the regression result of model one. It can be seem that the regression equation $\mathrm{R}^{2}=0.975$, which indicates that the model fits well. The variables including DISCORE, LEV, BM , BETA, SIZE are all significantly affected, and DISCORE has a significant negative impact. On the other hand, the regression coefficient of DISCORE is -0.004 and the probability of significance is 0.020 , which indicates that DISCORE has a significant negative correlation between the DISCORE and the COE at the significant level of $10 \%$. That is, the level of information disclosure of new energy listed companies and the cost of equity have a significant negative impact. The higher the level of information disclosure can enable enterprises to obtain lower capital costs.

TABLE III OLS RESULTS

\begin{tabular}{|c|c|c|c|}
\hline & Coefficient & t-value & p-value \\
\hline C & 0.188 & 2.068 & 0.039 \\
\hline DISCORE & -0.004 & -2.333 & 0.020 \\
\hline LEV & -0.010 & -2.979 & 0.003 \\
\hline BM & 0.003 & 3.329 & 0.000 \\
\hline BETA & -0.003 & -2.677 & 0.007 \\
\hline SIZE & -0.053 & -1.820 & 0.069 \\
\hline R-squared & 0.975 & & \\
\hline $\begin{array}{c}\text { Adj. R- } \\
\text { squared }\end{array}$ & 0.971 & & \\
\hline
\end{tabular}

From the results of model two regression in Table 4, it can be seen that there is a significant negative impact on the level of information disclosure (DISCORE). More importantly, the cross-variable information disclosure level* ${ }^{*}$ government subsidy (DISCORE*GOV) has a regression coefficient of 0.16553 , and the significance probability is 0.0123 , which less than 0.1. Therefore, the DISCORE*GOV has a significant positive correlation with the cost of equity at a significant level of $10 \%$. That is, there is a significant positive impact on the level of government subsidies and information disclosure, which is consistent with the expected hypothesis. It can be concluded that the new energy listed companies receiving government subsidies make the level of information disclosure to be improved accordingly, and thus enhance the trend of reducing the cost of equity.
TABLE IV TwO-STAGE OLS RESUlTS

\begin{tabular}{|c|c|c|c|}
\hline & Coefficient & t-value & p-value \\
\hline C & 0.188 & 2.069 & 0.039 \\
\hline DISCORE & -0.005 & -2.334 & 0.020 \\
\hline LEV & -0.011 & -2.979 & 0.003 \\
\hline BM & 0.003 & 3.329 & 0.001 \\
\hline BETA & -0.003 & -2.677 & 0.008 \\
\hline SIZE & -0.054 & -1.820 & 0.069 \\
\hline R-squared & 0.975 & & \\
\hline Adj. R-squared & 0.972 & & \\
\hline
\end{tabular}

\section{CONCLUSION}

The purpose of this paper is to explore the impact of the level of the information disclosure on the cost of equity funds. Taking the enterprise size, book to market ratio, liability ratio, systemic risk and other expected impact on the cost of equity as the control variable, and the government subsidies are used as the adjustment variable. The empirical results of the study show that there is a significant negative impact on the level of information disclosure and the cost of equity. The empirical results show that in the new energy industry, increasing the level of information disclosure of enterprises can reduce the asymmetry of information inside and outside the enterprise, and reduce the information risk and agent risk borne by investors, which make investors willing to reduce the necessary return rate. Then the company can obtain a relatively low cost of equity.

\section{REFERENCES}

[1] Botosan, C. A. (1997). Disclosure level and the cost of equity capital. Accounting review, 323-349.

[2] Botosan, C. A., \& Plumlee, M. A. (2002). A re-examination of disclosure level and the expected cost of equity capital. Journal of accounting research, 40(1), 21-40.

[3] Bushman, R. M., \& Smith, A. J. (2001). Financial accounting information and corporate governance. Journal of accounting and Economics, 32(13), 237-333..

[4] Chen, K. C., Wei, K. C., \& Chen, Z. (2003). Disclosure, corporate governance, and the cost of equity capital: evidence from Asia's emerging markets. Corporate Governance, and the Cost of Equity Capital: Evidence from Asia's Emerging Markets (June 2003).

[5] Chen, K. C., Chen, Z., \& Wei, K. C. (2004, October). Disclosure corporate governance, and the cost of equity capital in emerging markets. In American Accounting Association Annual Conference, Orlando, Florida.

[6] Chen, R. B., \&Xu, C. Y. (1991). The impact of information disclosure level on the cost of equity funds [D]. Soochow Economics, 61:67-108. (In Chinese)

[7] Copeland, T. E., \& Galai, D. (1983). Information effects on the bid-ask spread. the Journal of Finance, 38(5), 1457-1469.

[8] Easley, D., \& O'hara, M. (2004). Information and the cost of capital. The Journal of finance, 59(4), 1553-1583.

[9] Fama, E. F., \& French, K. R. (1992). The cross-section of expected stock returns. the Journal of Finance, 47(2), 427-465.

[10] Fama, E. F., \& French, K. R. (1993). Common risk factors in the returns on stocks and bonds. Journal of financial economics, 33(1), 3-56.

[11] Fama, E. F., \& French, K. R. (1997). Industry Costs of Capital. Journal of Financial Economics, 43(2): 153-93.

[12] Gode, D., \& Mohanram, P. (2003). Inferring the cost of capital using the Ohlson-Juettner model. Review of accounting studies, 8(4), 399-431. 
[13] Hail, L. (2002). The impact of voluntary corporate disclosures on the exante cost of capital for Swiss firms. European Accounting Review, 11(4), 741-773.

[14] Huang, J. J., \& Xiao, W. (2006). Information Disclosure, Income Opacity and Cost of Equity Capital [J]. China Accounting Review, 01:69-84. (In Chinese)

[15] Lv, J. Q. (2010). Industry and Enterprise Characteristics of Influencing Factors of Government Subsidy[J]. Shanghai Management Science, 32(04): 104-110. (In Chinese)

[16] Pittman, J. A., \& Fortin, S. (2004). Auditor choice and the cost of debt capital for newly public firms. Journal of accounting and economics, 37(1), 113-136.

[17] Rosenberg, B., Reid, K., \& Lanstein, R. (1985). Persuasive evidence of market inefficiency. The Journal of Portfolio Management, 11(3), 9-16.

[18] Skuras, D., Tsegenidi, K., \& Tsekouras, K. (2008). Product innovation and the decision to invest in fixed capital assets: Evidence from an SME survey in six European Union member states. Research Policy, 37(10), 1778-1789.

[19] Sun, S. X. (2010). Research on the relationship between information disclosure and capital cost of Chinese listed companies [D]. Capital University of Economics and Business. (In Chinese)

[20] Tang, L. (2018). Government subsidies, R\&D investment and environmental performance of listed companies in the new energy industry [D]. Chongqing Technology and Business University. (In Chinese)

[21] Tu, H. H. (2017). New revision of the "Government Subsidy" guidelines for in-depth exploration [J]. Think tank era, 12:277-279. (In Chinese)

[22] Verrecchia, R. E. (1999). Disclosure and the cost of capital: A discussion. Journal of accounting and economics, 26(1-3), 271-283.

[23] Wang, W., \& Jiang, G. F. (2004). Information Disclosure, Transparency and Capital Costs [J]. Economic Research, 07:107-114. (In Chinese)

[24] Wang, S. (2013). Research on Accounting Treatment and Information Disclosure of Government Subsidies in China's Listed Companies [D]. Institute of Fiscal Science, Ministry of Finance. (In Chinese)

[25] Wang, W. H., \& Shen, X. L. (2018). Research on the relationship between information disclosure quality and equity capital cost based on comparative study between high-tech industry and listed companies in the general industry [J]. Commercial Accounting, 01:71-73. (In Chinese)

[26] Yang, H., Jia, X. P., \& Li, H. S. (2016). Research on Accounting Treatment and Information Disclosure of Government Subsidies in China's Listed Companies[J]. Business Accounting, 13:26-29. (In Chinese)

[27] Zhang, Y., \& Guo, X. M. (2015). Internal Control Information Disclosure Quality, Disclosure Method and Equity Capital Cost—Evidence Based on Defect Information Disclosure[J]. Economic Issues, 04:110-115. (In Chinese) 